\title{
Anti-Idiotypic Antibodies and "Tumor-Only" Antigens: An Update
}

\author{
Alejandro López-Requena ${ }^{\mathrm{a}, \mathrm{b}}$ and Oscar R. Burrone ${ }^{*, \mathrm{~b}}$ \\ ${ }^{a}$ Department of Antibody Engineering, Center of Molecular Immunology, P.O. Box 16040, Havana 11600, Cuba \\ ${ }^{b}$ Molecular Immunology Group, International Centre for Genetic Engineering and Biotechnology, Padriciano 99,34012 \\ Trieste, Italy
}

\begin{abstract}
The use of anti-idiotypic antibodies for cancer treatment continues to be a major field of investigation. One major challenge for tumor immunotherapy is the identification of antigens associated only or preferably with malignant cells. We summarize here some of the most recent preclinical and clinical advances using two targets that can be considered tumor-specific antigens: $N$-glycolyl (NeuGc)-gangliosides and the idiotype of B cell lymphomas. Recent developments with tumor-associated protein antigens and the role of anti-idiotypic antibodies in autoimmune diseases are also discussed.
\end{abstract}

Keywords: Anti-idiotypic antibodies, NeuGc, ganglioside, idiotype, B cell lymphoma.

\section{INTRODUCTION}

From the pioneer works by Oudin and Kunkel [1, 2], where the existence of individual antigenic determinants of the immunoglobulins (idiotopes) was demonstrated, to Jerne's Idiotypic Network Theory [3]; through Bona's "regulatory idiotope" [4] and Coutinho's "second generation" networks [5], the theory around anti-idiotypic antibodies has been extensively discussed and often poorly proved. In spite of this, the search for anti-idiotypic antibodies (or Ab2) that could serve as mimics of protein and non-protein antigens has been carried out along with the development of "classic" monoclonal antibodies (mAbs) directed against "nominal" antigens (Ab1).

The classification of anti-idiotypic antibodies is illustrated in Fig. (1). The antibody induced by a given antigen is represented by Ab1, which recognizes a defined region of the antigen (the epitope) through the two variable regions of the light (VL) and heavy ( $\mathrm{VH}$ ) chains that constitute the idiotype. The part of the antibody molecule directly involved in epitope recognition is operationally defined as the paratope. Since the antibodies themselves can also be antigens, antibodies directed against the $\mathrm{Ab} 1$ variable regions (anti-Ab1 or Ab2) are generally known as anti-idiotypic antibodies. However, there are different types of Ab2: (i) $\mathbf{A b 2} \boldsymbol{\alpha}$ recognizes an idiotope (i.e: an epitope on the idiotype) not structurally related to the paratope of the Ab1; (ii) in contrast, antiidiotypic antibodies known as $\mathbf{A b 2} \boldsymbol{\beta}$ bind to the paratope on Ab1 and mimic the original epitope recognized by the Ab1 on the nominal antigen, which means that when performing as antigens they induce an anti-Ab2 response (Ab3) similar to the Ab1 (called Ab1'), thus able to recognize the antigen; these Ab2 $\beta$ are said to carry the "internal image" of the antigen epitope; and (iii) $\mathbf{A b 2} \gamma$ recognizes an idiotope structurally associated to the paratope but not able to mimic the antigen epitope, therefore inducing $\mathrm{Ab} 3$ unable to recognize the

\footnotetext{
*Address correspondence to this author at the Molecular Immunology Group, International Centre for Genetic Engineering and Biotechnology, Padriciano 99, 34012 Trieste, Italy; E-mail: burrone@ icgeb.org
}

antigen. The generation of anti-idiotypic antibodies against $\mathrm{Ab} 2$ (anti-Ab2 or Ab3) with the same specificity of the $\mathrm{Ab} 1$ (Ab1') can be impaired by the peripheral tolerance mechanisms of the organism even when the Ab2 carries the "internal image" of the antigen [6].

Anti-idiotypic antibodies have been widely used for cancer immunotherapy [7]. In this short review, we will discuss some of the most recent works published in two main fields: (i) the use of anti-idiotypic antibodies of the $A b 2 \beta$ type as antigens to mimic a particular kind of carbohydrate antigen (gangliosides) expressed on tumor cells; and (ii) idiotypic vaccines, using the idiotype of B cell lymphomas as antigens to induce anti-tumor idiotype-specific immune responses. Finally, we comment recent results on the mimic of tumor protein antigens and on the role of anti-idiotypic antibodies in preventing autoimmune diseases.

\section{ANTI-IDIOTYPIC ANTIBODIES AND NON-PROTEIN ANTIGENS: THE GANGLIOSIDE CASE}

The first evidences of the association between gangliosides, glycosphyngolipids with sialic acid residues in their structure, and cancer cells came from studies made in the seventies $[8,9]$. The selection of gangliosides as potential targets for cancer therapy is still a current line of investigation [10].

Several well-characterized anti-idiotypic antibodies (Ab2 $\beta$ against anti-ganglioside Ab1) mimicking gangliosides have been tested as therapeutic molecules on some human cancers [11]. The most extensively studied is Bec2 $\mathrm{mAb}$, which mimics the $\mathrm{N}$-acetylated form of neuraminic acid (sialic acid) on ganglioside GD3 (NeuAc-GD3) [12]. This $\mathrm{Ab} 2$ has been tested in patients with tumors of neuroectodermal origin, as melanoma and small cell lung cancer (SCLC) [13]. However, a phase III clinical trial with Bec2/bacille Calmette-Guerin (BCG) in patients with SCLC failed to prolong overall survival, progression-free survival and quality of life. An antibody response against NeuAcGD3 was observed only in one third of patients, but even within this group there was not a significant increase in survival [14]. 

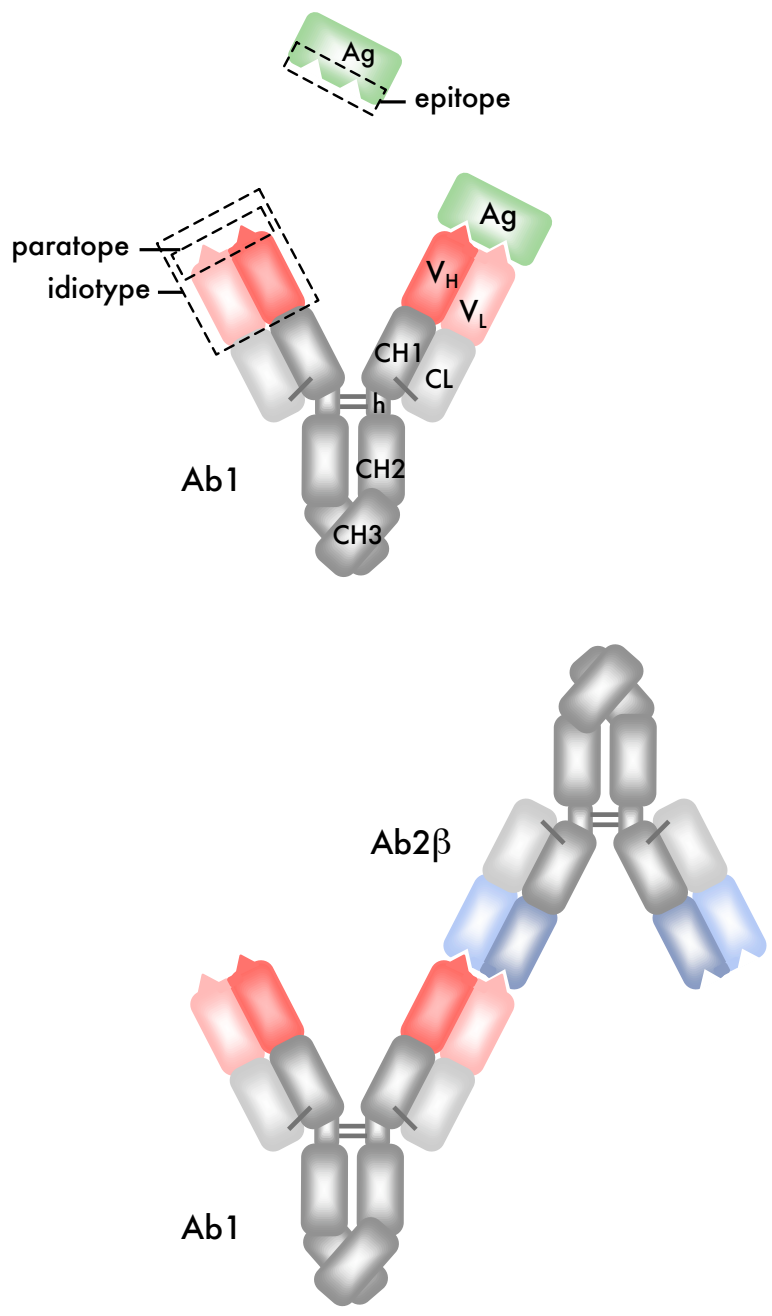
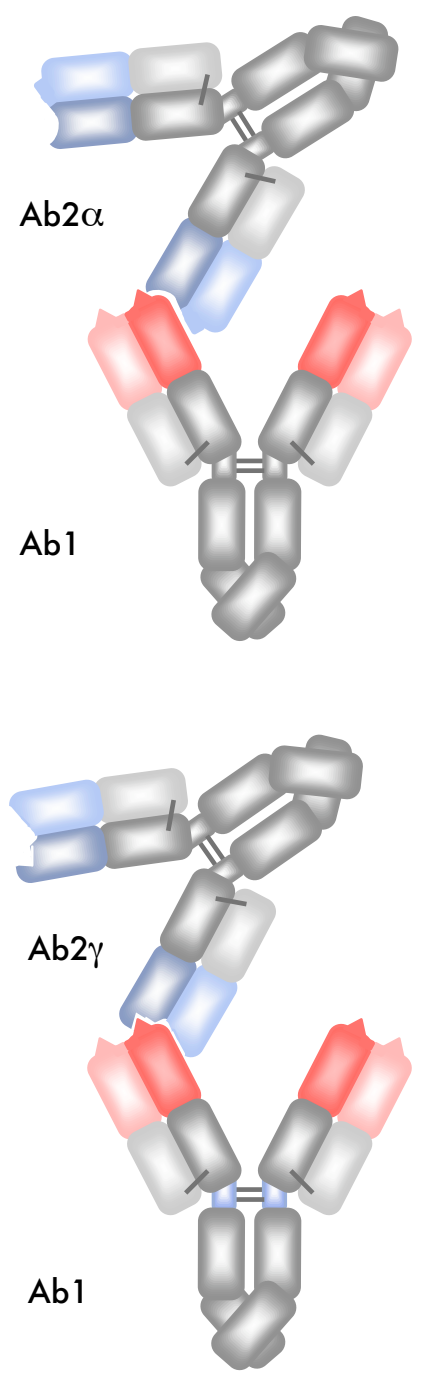

Fig. (1). Scheme of an antigen/antibody (Ab1, $\lg$ class), interaction and the three possible anti-idiotypic Ab2 antibodies.

Recently, a new cancer vaccine candidate Ab2 was derived from a neuroblastoma patient [15] treated with an antiNeuAc-GD2 ganglioside mAb (Ab1) [16]. B cells of the patient were used to isolate $\mathrm{Ab} 2$ antibodies through the construction of phage libraries. Two such antibodies, able to induce anti-ganglioside antibodies in vaccinated rabbits were identified. One of them (GK8) was proposed as a potential vaccine for NeuAc-GD2-expressing tumors, due to its ability to inhibit binding of Ab1 to the ganglioside as well as binding of $\mathrm{Ab} 2 \mathrm{~s}$ from the patient's serum to the Ab1 [15].

\section{TUMOR-SPECIFIC N-GLYCOLYL-SIALIC ACID- CONTAINING GANGLIOSIDES}

Glycoconjugates bearing the $\mathrm{N}$-glycolylated variant of sialic acid (NeuGc) instead of the $N$-acetylated (NeuAc) are widely distributed in most mammals, while in human normal tissues are not present [17]. The enzymatic hydroxylation of the $N$-acetyl group in the sialic acid bound to CMP is the major mechanism for the biosynthesis of $\mathrm{N}$-glycolyl-sialic acid [18]. In humans, the gene coding for the CMP-NeuAc hydroxylase has a deletion that renders it inactive [19-21]. However, a number of studies have reported the presence of these glycoconjugates as tumor-associated antigens in sev- eral human malignant diseases [22-24]. It has recently been reported the expression of small amounts of $\mathrm{N}$-glycolyl-sialic acid in some human normal tissues that were attributed to dietary sources $[25,26]$. The incorporation of the NeuGc residues can occur selectively in human tumor cells adapted to hypoxia, through an increased activity of a specific cellular transporter for sialic acid [27]. The NeuGc moiety is found for instance associated to GM3 forming NeuGc-GM3 ganglioside. Interestingly, the importance of NeuGc-GM3 in both, tumor-induced immunosuppresion and tumor development has recently been demonstrated [28-30].

P3 is a mAb specific for the NeuGc group, generated by immunizing mice with NeuGc-GM3 [31]. However, P3 can bind to different NeuGc-containing gangliosides [31, 32]. Several monoclonal Ab2s against P3 have been reported [33, 34]. The most studied one is 1E10 [33], which is the only antiidiotypic mAb currently in clinical trials able to mimic NeuGc-gangliosides [35]. Interestingly, the ability of murine $1 \mathrm{E} 10$ to induce Ab1' antibodies (i.e.: able to bind to NeuGc) was demonstrated to be dependent on the nature of the antigen in the animal species tested. In other words, vaccination with $1 \mathrm{E} 10$ induces Ab3 antibodies able to bind NeuGc-gangliosides only in those species where these glycoconjugates are non-self 
antigens, i.e., chickens and humans, whereas in mice and monkeys, which express NeuGc-gangliosides in their normal tissues, it induces antibodies that do not recognize these antigens $[6,33]$, suggesting a strong operating mechanism of tolerance.

The generation of both $\operatorname{IgM}$ and $\operatorname{IgG}$ antibodies against NeuGc-GM3, but not against its $N$-acetylated variant (NeuAcGM3), through a vaccine consisting of mAb $1 \mathrm{E} 10$ in alum was originally demonstrated in patients with melanoma [36] and breast cancer [37], and more recently in phase I clinical trials of patients with breast cancer [38], SCLC [39] and non-small cell lung cancer (NSCLC) [40]. The existence of such antibodies has been confirmed by several methods, including ELISA, cytofluorimetry and high-performance thin layer chromatography [36-40].

$1 \mathrm{E} 10 \mathrm{mAb}$ does not need adjuvants other than alum to induce $\mathrm{Ab} 3$ responses, including $\mathrm{Ab1}$ ', in most of the vaccinated patients from the different trials mentioned above. The antibody response against the idiotype of $1 \mathrm{E} 10$ was significantly higher than the response against the isotype (i.e: human anti-mouse IgG) [36, 37, 40], with the obvious advantage of increasing the generation of the desired ganglioside-binding antibodies while diminishing the adverse effects often associated with the human anti-mouse isotype response. In addition, immunization with 1E10 induces, both in chickens and humans a subset of antibodies unable to recognize 1E10, yet with reactivity against NeuGc-GM3, which could be the result of the induction of anti-idiotypic cascades [6, 36, 37, 40].

Upon immunization with 1E10, in addition to the antibody response, a cellular specific response was demonstrated in some vaccinated breast cancer patients. In fact, interferon gamma (IFN $\gamma$ )-secreting cells were detected when pheripheral blood mononuclear cells (PBMC) from such patients were incubated in vitro with dendritic cells pulsed with liposomes containing NeuGc-GM3 [38]. Moreover, antibodies from $1 \mathrm{E} 10$ vaccinated patients were able to induce complementindependent cell death in a NeuGc-GM3-expressing murine tumor cell line [40]. Interestingly, another mAb specific only for NeuGc-GM3, named 14F7 [41], exhibits a cytotoxic activity also independent of complement $[42,43]$. The mechanism of cell death is different from apoptosis, dependent on the ganglioside and involves loss of membrane integrity [43].

The clinical outcome of the 1E10 vaccination trials on SCLC [39] and on stage IIIb/IV patients with NSCLC [44] showed a trend towards prolonged survival of vaccinated patients compared with historical controls. Even more encouraging, the development by NSCLC patients of IgM and/or IgG antibodies against NeuGc-GM3 was positively correlated with longer survival [40]. Phase II trials with the $1 \mathrm{E} 10$ vaccine in breast cancer, SCLC and NSCLC patients are currently ongoing to better define the clinical impact associated with the immunological response.

\section{B CELL LYMPHOMAS: THE "MODEL" DISEASE FOR ANTI-IDIOTYPIC THERAPY}

The idiotype of the membrane-bound immunoglobulin expressed on the surface of a cancer B cell is perhaps the only true tumor-specific antigen. The clonality of the events that lead to the malignant transformation of a B cell is a major challenge to immunotherapy and at the same time, a unique opportunity for the design of personalized vaccines.
Indeed, the idiotype of the immunoglobulin expressed by the malignant cells is unique among all B cells and therefore can be used as an antigen to induce an anti-idiotype specific immune response. While the complete immunoglobulin of the lymphoma has been used as antigen, the idiotype is frequently engineered into the $\mathrm{scFv}$ format, which contains only the two variable regions linked through a flexible peptide linker (Fig. 2a). In contrast to antigen-mimicking, the antiidiotypic antibodies induced in this case, directly recognize the tumor antigen (i.e., the idiotype of the immunoglobulin) and mediate effector functions.

However, an important obstacle for achieving an effective immune response against this antigen is represented by the need to break the immunological tolerance against the self idiotype. In fact, despite the clonality and uniqueness of the sequences encoding the two variable regions that form the idiotype, most of the variable regions are constituted by highly conserved sequences (the so-called frameworks). Variable regions are the consequence of gene rearrangements in the bone marrow B cell precursors and of somatic hypermutations in activated mature B cells. Most amino acid differences between variable regions of different antibodies however, are found in the loops making contact with antigen (complementary-determining regions: CDRs), while the remaining constitute the more conserved frameworks regions (Fig. 2b). Several strategies have been tested to achieve breakdown of tolerance, from the use of conventional immunostimulatory compounds, to vaccines based on dendritic cells or DNA [45-48].

As an alternative to constructing and expressing the idiotypic antigens for individual vaccines, which can be laborious and time-consuming, a vaccine formulation consisting in an extract of membrane proteins from tumor cells incorporated into proteoliposomes together with interleukin-2 (IL-2) has recently been proposed. This preparation was effective in inducing antitumor responses in mice at low doses of antigen [49]. In a pilot clinical trial on follicular lymphoma, tumorspecific responses were observed in some patients with advanced disease, although tumor progression was not affected. However, anti-idiotypic antibodies were not detected and an idiotypic-specific $\mathrm{T}$ cell response was demonstrated only in one out of four evaluated patients [50].

An advantage for the treatment of B cell lymphomas via induction of anti-idiotypic antibodies is represented by the fact that the expression and signaling of the membrane bound immunoglobulin constituting the $\mathrm{B}$ cell receptor (BCR), is critical for cell survival and proliferation [51]. Although idiotypic variants can arise due to genetic instability of tumor cells, patients vaccinated with their original own tumor-specific idiotype can develop an effective polyclonal response despite the heterogeneity of lymphoma cells [52]. In fact, in a follow-up study of average 100 months after vaccination, most of the patients that received their own tumor idiotypic protein (i.e: the secretory version of the membrane-associated immunoglobulin of the lymphoma) coupled to the carrier protein keyhole limpet haemocyanin (KLH) were in clinical remission, and some of them also in molecular remission [53]. Besides the anti-idiotypic antibody response, the clinical outcome depends on the Fc receptor genotype $[54,55]$ while chemotherapy prior to vaccination has been shown to be irrelevant [55]. Patients homozygous 


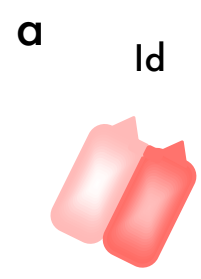

Id in scFv format

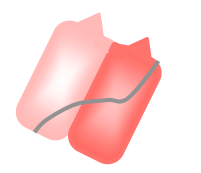

Id-SIP

hu- $\gamma 1 \mathrm{CH} 3$

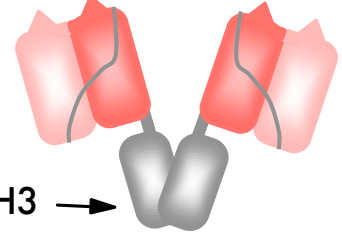

b

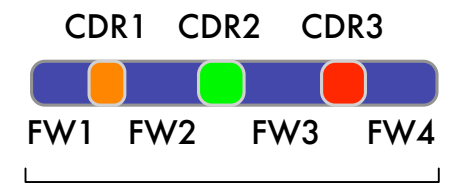

$\checkmark$ region
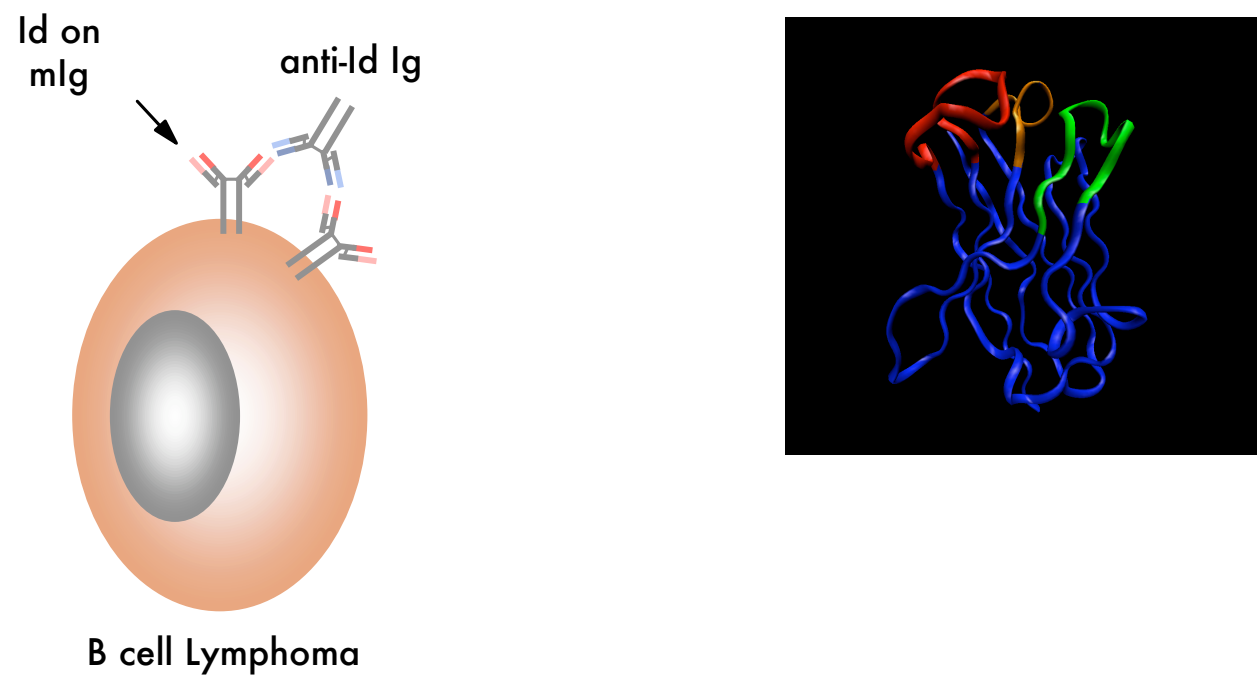

Fig. (2). (a) The idiotype (Id) and the $\mathrm{scFv}$ format in which the two variable regions are fused through a flexible peptide. A CH3 domain from a human IgG1 (hu- $\gamma 1 \mathrm{CH} 3)$ was used as a T cell epitope carrier to render immunogenic the Id of a murine B cell lymphoma. SIP: small immune protein. (b) Representation of a variable (V) region showing the location of CDRs (orange, green and red) in the linear primary sequence and in the folded domain. All four framework regions (FW) are shown in blue.

for a particular allele of Fc $\gamma$ RIIIa bearing a valine residue at position 158 showed longer progression free survival [54, 55]. The polymorphism of Fc $\gamma$ receptors (Fc $\gamma \mathrm{Rs})$ can affect their affinity for the Fc of the antibodies, thus enhancing the efficiency of the antibody-dependent cellular cytotoxicity (ADCC) $[56,57]$ or the Fc $\gamma$ R-mediated antigen delivery and activation of dendritic cells [58, 59]. Surprisingly, the antitumor effect of anti-idiotypic antibodies directed against cell surface-associated idiotypes has been also verified on plasmacytoma cells, which do not express membrane-bound immunoglobulins. Probably, a small amount of secreted antibodies retained in a non-specific way on the cell surface, or alternatively a minimal expression of membrane-bound immunoglobulin, is enough for tumor growth impairment by anti-idiotypic antibodies [60]. Additionally, vaccination with the patient's own tumor idiotype can induce not only humoral but also cellular responses [52]. Current works in B cell lymphoma immunotherapy include a vaccine consisting in the unique idiotype from the patient chemically conjugated to KLH and co-administered with granulocytemacrophage colony-stimulating factor (GM-CSF) [61]. At present, this vaccine is being tested in a phase III clinical trial in follicular B cell non-Hodgkin's lymphoma [62].

There is, however, a current polemic about the role of cytotoxic $\mathrm{T}$ cells in B cell lymphoma progression [63, 64]. Some reports correlate the presence and activity of cytotoxic $\mathrm{T}$ cells with poor disease prognosis [65-67], while others state that infiltrates of both dendritic and $\mathrm{T}$ cells correspond to a favorable prognosis [68]. In the case of helper $T$ cells, a recent report showed that infrequent Th2 cells specific for rare idiotopes could promote B cell lymphoma development, probably through the continuous induction of proliferation of idiotope-presenting B cell, thus augmenting the probability of oncogenic transformation [69].

\section{GENETIC VACCINATION FOR B CELL LYM- PHOMA TREATMENT}

DNA vaccines are based on the administration of the gene encoding the antigen rather than the antigen itself. Antigen-specific antibodies and $\mathrm{T}$ cell responses can be induced by delivering the DNA in a number of ways promoting the expression of antigen in different cell types. An important aspect is constituted by the presence of immunostimulatory nucleotide sequences of bacterial origin [70,71], which can induce inflammatory responses through activation of dendritic cells via Toll-like receptor 9 [72, 73]. We have previously demonstrated [74] that gene gun immunization is effective in inducing anti-idiotypic antibodies in the syngeneic model against a non-autoimmunogenic idiotype delivered as $\mathrm{scFv}$ fused to the murine $\gamma 1 \mathrm{CH} 3$ domain, which upon expression dimerizes as a SIP (small immune protein) (Fig. 2a) [75]. The same DNA construct, however, when delivered by infection with a recombinant adeno-associated virus (rAAV, produced in mammalian cells), failed to generate a humoral 
response against the idiotype [74]. In spite of this, a clear boosting effect on the anti-idiotypic antibody response and tumor rejection upon challenge was recently described for a rAAV encoding a lymphoma $\mathrm{scFv}$, when administered after an initial priming with the same DNA construct by gene gun delivery, although in this case the $\mathrm{scFv}$ was fused to the xenogeneic human $\gamma 1 \mathrm{CH} 3$ domain as a carrier of $\mathrm{T}$ helper epitopes required to break tolerance [76]. DNA constructs for immunization can also include immunostimulatory molecules. A DNA vaccine consisting in the coinjection of two different plasmids encoding one, the tumor idiotype and the other the heat shock protein 70 from Mycobacterium tuberculosis was effective in prolonging survival of mice challenged with the 38C13 B cell lymphoma. However, no differences were observed with a construct in which the idiotype (in a scFv format) was fused to the GM-CSF sequence or even when the plasmid containing only the idiotype was used. Surprisingly, although all three groups of mice developed anti-idiotypic IgG2b antibodies, only in the two latter cases IgG1 and IgG2a antibodies were detected [77].

We have used DNA vaccination strategies in the murine BCL1 B cell lymphoma model [78]. Our results demonstrated that anti-idiotypic antibodies were responsible for protection against tumor challenge. In fact, vaccination with hybrid constructs consisting in the BCL1 VH or VL combined with irrelevant VL and $\mathrm{VH}$, respectively, did not induce antibodies against the tumor-derived VL/VH combined idiotype [79, 80], and did not prevent tumor development, even when both hybrid constructs were co-administered. Moreover, in vitro the anti-idiotypic antibodies induced apoptosis and cell cycle arrest in idiotype-expressing cells, although they were not completely eradicated even in longlasting surviving mice [80].

\section{RECENT DEVELOPMENTS IN TUMOR PROTEIN ANTIGEN MIMICKRY WITH ANTI-IDIOTYPIC AN- TIBODIES}

The antigen-mimicking approach through the use of antiidiotypic antibodies for tumor therapy is far to be discarded, despite some unsuccessful results. Several types of cancers are nowadays being treated with anti-idiotypic antibodies mimicking protein antigens.

A vaccine consisting in an anti-idiotypic antibody (105AD7) able to mimic a glycoprotein (CD55) overexpressed in colorectal cancer (CRC) cells induced cellular responses in patients against both the antigen and the Ab2. These responses were measured through $\mathrm{T}$ cell assays (IFN $\gamma$ ELISPOT and proliferation assay) and cytokine (tumor necrosis factor alpha, TNF $\alpha$ and GM-CSF) determination (Luminex). Interestingly, there was no correlation between the IFN $\gamma$-secreting cell numbers and the proliferation assays, indicating probably the measurements of different $\mathrm{T}$ cell populations [81]. This antibody has also been tested in patients with osteosarcoma [82]. As in the previous CRC trial [81], T cell responses against both the antibody and the antigen were generated. A positive correlation between GM-CSF and TNF $\alpha$ secretion (Luminex), but not between these molecules and IFN $\gamma$ (ELISPOT), was observed [82].

The induction of antigen-specific $\mathrm{T}$ cell responses was also demonstrated in another study on CRC patients vaccinated with either a human Ab2 mimicking a tumor- associated glycoprotein (Ep-CAM; higher expression in malignant cells from epithelial origin), the antigen alone or a combination of both. It was found however that the two latter immunogens were more effective than the antibody alone in inducing a cellular response [83].

Anti-idiotypic vaccines targeting different antigens coexpressed in certain tumors have also been combined. A recent phase II clinical trial with anti-carcinoembryonic antigen (CEA) and anti-human milk fat globule (HMFG) antiidiotypic antibodies (CeaVac and TriAb, respectively) after resection of $\mathrm{CRC}$ hepatic metastasis, failed to improve recurrence-free survival in comparison with surgery alone [84].

The association of the Her family of tyrosine kinase receptors with tumors has been extensively described. A humanized mAb targeting Her-2 extracellular domain, called Trastuzumab (Herceptin) [85], is one of the main current approaches for immunotherapy of Her-2-expressing tumors. An anti-idiotypic antibody (6D12) [86] against 4D5, the murine version of Trastuzumab [87], mimics a specific epitope of this receptor [86]. 6D12 induces in mice anti-antiidiotypic antibodies (Ab3) able to inhibit in vitro proliferation of Her-2-positive tumor cells, and to exert ADCC [86, 88 ] and protection against challenge with these cells [88].

\section{BEYOND MIMICKRY AND TUMOR IDIOTYPE BINDING}

Anti-idiotypic antibodies have been implicated in several immune conditions, including sperm immunity in women [89]. However, although Jerne proposed anti-idiotypic interactions as a mechanism for immune response and memory regulation, still little is understood about how anti-idiotypic antibodies can modulate the immune system.

Intravenous immunoglobulins (IVIg) have been used for a wide range of immune-associated pathologies, including autoimmune diseases. A putative mechanism of action is the neutralization of pathologic autoantibodies by anti-idiotypic antibodies [90, 91]. According to Jerne's theory, self idiotypes can elicit a natural antibody response. In fact, it was recently demonstrated that antibodies against the self antigen glutamate decarboxylase 65 were present in patients with type 1 diabetes and in their first-degree relatives, as well as in healthy individuals in general. However, only patients with type 1 diabetes lacked a bound "inhibitor" that was present in the other two groups. The inhibitor was identified as anti-idiotypic antibodies [92]. Previously, it had been shown that when injected in non-obese diabetic (NOD) mice, a human anti-glutamate decarboxylase 65 antibody induced an anti-idiotypic antibody response able to block the antigenantibody interaction, delaying the onset of the disease [93]. We have recently proposed that the existence in normal individuals of autoantibodies exhibiting high idiotypic immunogenicity could precisely be a mechanism of regulation of self-reactive antibodies [94]. The molecular basis for polyreactive anti-idiotypic antibodies with immunoglobulin crossreactive activity have recently been postulated [95].

\section{CONCLUDING REMARK}

Although the existence of natural or induced idiotypic networks is still a matter of debate, anti-idiotypic antibodies continue to be a very interesting tool for the treatment of malignant or autoimmune diseases. One major technological 
issue is augmenting the immunogenicity of anti-idiotypic antibody-based vaccines, if mimickry of the antigen or the anti-tumor idiotype response are the desired goals. Additionally, understanding how idiotypic interactions may play a role in the regulation of the immune system, would bring the possibility of manipulating the immune actors to achieve effective and long-lasting immunological responses or modulating immune-related pathological conditions.

\section{ACKNOWLEDGEMENTS}

We thank Drs. Cristina Mateo de Acosta and Ana María Vázquez (Center of Molecular Immunology, CIM, Havana, Cuba) for critical review of the manuscript. This work was supported by the CIM and the International Center for Genetic Engineering and Biotechnology (ICGEB, Trieste, Italy).

\section{REFERENCES}

[1] Oudin J, Michel M. Une nouvelle forme d'allotypie des globulines du serum de lapin, apparemment liée à la foction et à la spécificité des anticorps. C R Acad Sci (Paris) 1963; 275: 805-8.

[2] Grey HM, Mannik M, Kunkel HG. Individual antigenic specificity of myeloma proteins. Characteristics and localization to subunits. J Exp Med 1965; 121: 561-75.

[3] Jerne NK. Towards a network theory of the immune system. Ann Immunol Paris 1974; 125C: 373-89.

[4] Bona CA, Heber-Katz E, Paul WE. Idiotype-anti-idiotype regulation. I. Immunization with a levan-binding myeloma protein leads to the appearance of auto-anti-(anti-idiotype) antibodies and to the activation of silent clones. J Exp Med 1981; 153: 951-67.

[5] Coutinho A. The network theory: 21 years later. Scand J Immunol 1995; 42: 3-8.

[6] Hernandez AM, Rodriguez M, Lopez-Requena A, Beausoleil I, Perez R, Vazquez AM. Generation of anti-Neu-glycolylganglioside antibodies by immunization with an anti-idiotype monoclonal antibody: A self versus non-self matter. Immunobiology 2005; 210: 11-21.

[7] de Cerio AL, Zabalegui N, Rodriguez-Calvillo M, Inoges S, Bendandi M. Anti-idiotype antibodies in cancer treatment. Oncogene 2007; 26: 3594-602.

[8] Irie RF, Irie K, Morton DL. A membrane antigen common to human cancer and fetal brain tissues. Cancer Res 1976; 36: 3510-17.

[9] Portoukalian J, Zwingelstein G, Dore J. Lipid composition of human malignant melanoma tumors at various levels of malignant growth. Eur J Biochem 1979; 94: 19-23.

[10] Livingston PO, Hood C, Krug LM, et al. Selection of GM2, fucosyl GM1, globo $\mathrm{H}$ and polysialic acid as targets on small cell lung cancers for antibody mediated immunotherapy. Cancer Immunol Immunother 2005; 54: 1018-25.

[11] Bhattacharya-Chatterjee M, Chatterjee SK, Foon KA. Anti-idiotype vaccine against cancer. Immunol Lett 2000; 74: 51-8.

[12] Chapman PB, Houghton AN. Induction of IgG antibodies against GD3 ganglioside in rabbits by an anti-idiotypic monoclonal antibody. J Clin Invest 1991; 88: 186-92.

[13] Chapman PB. Vaccinating against GD3 ganglioside using BEC2 anti-idiotypic monoclonal antibody. Curr Opin Investig Drugs 2003; 4: 710-5.

[14] Giaccone G, Debruyne C, Felip E, et al. Phase III study of adjuvant vaccination with Bec2/bacille Calmette-Guerin in responding patients with limited-disease small-cell lung cancer (European Organisation for Research and Treatment of Cancer 08971-08971B; Silva Study). J Clin Oncol 2005; 23: 6854-64.

[15] Uttenreuther-Fischer MM, Krüger JA, Fischer P. Molecular characterization of the anti-idiotypic immune response of a relapse-free neuroblastoma patient following antibody therapy: a possible vaccine against tumors of neuroectodermal origin? J Immunol 2006; 176: 7775-86.

[16] Mueller BM, Romerdahl CA, Gillies SD, Reisfeld RA. Enhancement of antibody-dependent cytotoxicity with a chimeric anti-GD2 antibody. J Immunol 1990; 144: 1382-6.

[17] Varki A. N-glycolylneuraminic acid deficiency in humans. Biochimie 2001; 83: 615-22.
[18] Shaw L, Schauer R. The biosynthesis of N-glycoloylneuraminic acid occurs by hydroxylation of the CMP-glycoside of Nacetylneuraminic acid. Biol Chem Hoppe Seyler 1988; 369: 47786.

[19] Chou HH, Takematsu H, Díaz S, et al. A mutation in human CMPsialic acid hydroxylase occurred after the Homo-Pan divergence. Proc Natl Acad Sci USA 1998; 95: 11751-6.

[20] Irie A, Suzuki A. CMP-N-acetylneuraminic acid hydroxilase is exclusively inactive in humans. Biochem Biophys Res Comun 1998; 248: 330-3.

[21] Olson MV, Varki A. Sequencing the chimpanzee genome: insights into human evolution and disease. Nat Rev Genet 2003; 4: 20-8.

[22] Marquina G, Waki H, Fernández LE, et al. Gangliosides expressed in human breast cancer. Cancer Res 1996; 56: 5165-71.

[23] Malykh YN, Schauer R, Shaw L. N-Glycolylneuraminic acid in human tumours. Biochimie 2001; 83: 623-34.

[24] Kannagi R, Yin J, Miyazaki K, Izawa M. Current relevance of incomplete synthesis and neo-synthesis for cancer-associated alteration of carbohydrate determinants-Hakomori's concepts revisited. Biochim Biophys Acta 2008; 1780: 525-31.

[25] Tangvoranuntakul P, Ganneux P, Díaz S, et al. Human uptake and incorporation of an immunogenic nonhuman dietary sialic acid. Proc Natl Acad Sci USA 2003; 100: 12045-50.

[26] Bardor M, Nguyen DH, Díaz S, Varki A. Mechanism of uptake and incorporation of the non-human sialic acid $\mathrm{N}$-glycolylneuraminic acid into human cells. J Biol Chem 2005; 280: 4228-37.

[27] Yin J, Hashimoto A, Izawa M, et al. Hypoxic culture induces expression of sialin, a sialic acid transporter, and cancer-associated gangliosides containing non-human sialic acid on human cancer cells. Cancer Res 2006; 66: 2937-45.

[28] de Leon J, Fernandez A, Mesa C, Clavel M, y Fernandez, LE. Role of tumour-associated $\mathrm{N}$-glycolylated variant of GM3 ganglioside in cancer progression: effect over CD4 expression on T cells. Cancer Immunol Immunother 2006; 55: 443-50.

[29] de Leon J, Fernandez A, Clavell M, et al. Differential influence of the tumour-specific non-human sialic acid containing GM3 ganglioside on CD4+CD25- effector and naturally occurring CD4+CD25+ regulatory T cells function. Int Immunol 2008; 20: 591-600.

[30] Potapenko M, Shurin GV, de Leon J. Gangliosides as immunomodulators. Adv Exp Med Biol 2007; 601: 195-203.

[31] Vazquez AM, Alfonso M, Lanne B, et al. Generation of a murine monoclonal antibody specific for $\mathrm{N}$-glycolylneuraminic acidcontaining gangliosides that also recognizes sulfated glycolipids. Hybridoma 1995; 14: 551-6.

[32] Moreno E, Lanne B, Vazquez AM, et al. Delineation of the epitope recognized by an antibody specific for N-glycolylneuraminic acidcontaining gangliosides. Glycobiology 1998; 8: 695-705.

[33] Vazquez AM, Perez A, Hernandez AM, et al. Syngeneic antiidiotypic monoclonal antibodies to an anti-NeuGc-containing ganglioside monoclonal antibody. Hybridoma 1998; 17: 527-34.

[34] Lopez-Requena A, Rodriguez M, de Acosta CM, et al. Gangliosides, $\mathrm{Ab} 1$ and $\mathrm{Ab} 2$ antibodies II. Light versus heavy chain: An idiotype-anti-idiotype case study. Mol Immunol 2007; 44: 1015-28.

[35] Fernandez LE, Alonso DF, Gomez DE, Vazquez AM. Gangliosidebased vaccines and anti-idiotype antibodies for active immunotherapy against cancer. Expert Rev Vaccines 2003; 2: 89-95.

[36] Alfonso M, Diaz A, Hernandez AM, et al. An anti-idiotype vaccine elicits a specific response to $\mathrm{N}$-glycolyl sialic acid residues of glycoconjugates in melanoma patients. J Immunol 2002; 168: 2523-9.

[37] Diaz A, Alfonso M, Alonso R, et al. Immune responses in breast cancer patients immunized with an anti-idiotype antibody mimicking NeuGc-containing gangliosides. Clin Immunol 2003; 107: 809.

[38] Guthmann MD, Castro M, Cinat G, et al. Cellular and humoral anti-ganglioside response after prolonged anti-idiotypic immunotherapy in breast cancer patients. J Immunother 2006; 29: 215-23.

[39] Neninger E, Diaz RM, de la Torre A, et al. Active immunotherapy with $1 \mathrm{E} 10$ anti-idiotype vaccine in patients with small cell lung cancer: report of a phase I trial. Cancer Biol Ther 2007; 6: 145-50.

[40] Hernandez AM, Toledo D, Martinez D, et al. Characterization of the antibody response against NeuGcGM3 ganglioside elicited in non-small cell lung cancer patients immunized with an antiidiotype antibody. J Immunol 2008; 181: 6625-34. 
[41] Carr A, Mullet A, Mazorra Z, et al. A mouse IgG1 monoclonal antibody specific for N-glycolyl GM3 ganglioside recognized breast and melanoma tumors. Hybridoma 2000; 19: 241-7.

[42] Carr A, Mesa C, Arango MC, Vazquez AM, Fernandez LE. In vivo and in vitro anti-tumor effect of 14F7 monoclonal antibody. Hybrid Hybridomics 2002; 21: 463-8.

[43] Roque-Navarro L, Chakrabandhu K, de León J, et al. Antiganglioside antibody-induced tumor cell death by loss of membrane integrity. Mol Cancer Ther 2008; 7: 2033-41.

[44] Alfonso S, Diaz RM, de la Torre A, et al. 1E10 Anti-Idiotype Vaccine in Non-Small Cell Lung Cancer: Experience in Stage IIIb/IV Patients. Cancer Biol Ther 2007; 6: 1847-52.

[45] Benvenuti F, Cesco-Gaspere M, Burrone OR. Anti-idiotypic DNA vaccines for B-cell lymphoma therapy. Front Biosci 2002; 7: d22834

[46] Benvenuti F, Burrone OR. Genetic vaccination for the immunotherapy of B-cell malignancies. Curr Gene Ther 2002; 2: 235-42.

[47] Dermime S, Gilham DE, Shaw DM, et al. Vaccine and antibodydirected $\mathrm{T}$ cell tumour immunotherapy. Biochim Biophys Acta 2004; 1704: 11-35.

[48] Dermime S, Aljurf MD. Current advances, problems and prospects for vaccine-based immunotherapy in follicular non-Hodgkin's lymphoma. Leuk Lymphoma 2005; 46: 497-507.

[49] Popescu MC, Robb RJ, Batenjany MM, et al. A novel proteoliposomal vaccine elicits potent antitumor immunity in mice. Blood 2007; 109: 5407-10.

[50] Neelapu SS, Gause BL, Harvey L, et al. A novel proteoliposomal vaccine induces antitumor immunity against follicular lymphoma. Blood 2007; 109: 5160-3.

[51] Gururajan M, Jennings CD, Bondada S. Cutting edge: constitutive $\mathrm{B}$ cell receptor signaling is critical for basal growth of B lymphoma. J Immunol 2006; 176: 5715-9.

[52] Yañez R, Barrios Y, Cabrera R, Diaz-Espada F. Intraclonal variability of $\mathrm{VH}$ genes in follicular lymphoma patients who have received anti-idiotypic immunotherapy. J Immunother 2006; 29: 616.

[53] Yañez R, Barrios Y, Ruiz E, Cabrera R, Diaz-Espada F. Antiidiotypic Immunotherapy in Follicular Lymphoma Patients: Results of a Long Follow-up Study. J Immunother 2008; 31: 310-2.

[54] Weng WK, Czerwinski D, Timmerman J, Hsu FJ, Levy R. Clinical outcome of lymphoma patients after idiotype vaccination is correlated with humoral immune response and immunoglobulin $\mathrm{G}$ Fc receptor genotype. J Clin Oncol 2004; 22: 4717-24.

[55] Weng WK, Czerwinski D, Levy R. Humoral immune response and immunoglobulin G Fc receptor genotype are associated with better clinical outcome following idiotype vaccination in follicular lymphoma patients regardless of their response to induction chemotherapy. Blood 2007; 109: 951-3.

[56] Wu J, Edberg JC, Redecha PB, et al. A novel polymorphism of FcgammaRIIIa (CD16) alters receptor function and predisposes to autoimmune disease. J Clin Invest 1997; 100: 1059-70.

[57] Koene HR, Kleijer M, Algra J, et al. Fc gammaRIIIa-158V/F polymorphism influences the binding of IgG by natural killer cell Fc gammaRIIIa, independently of the Fc gammaRIIIa-48L/R/H phenotype. Blood 1997; 90: 1109-14.

[58] Amigorena S, Bonnerot C. Fc receptors for IgG and antigen presentation on MHC class I and class II molecules. Semin Immunol 1999; 11: 385-90.

[59] Kalergis AM, Ravetch JV. Inducing tumor immunity through the selective engagement of activating Fcgamma receptors on dendritic cells. J Exp Med 2002; 195: 1653-9.

[60] Moshitzky S, Kukulansky T, Haimovich J, Hollander N. Growth inhibition of myeloma cells by anti-idiotype antibodies in the absence of membrane-bound immunoglobulin. Immunol Cell Biol 2008; 86: 261-7.

[61] Hurvitz SA, Timmerman JM. Recombinant, tumour-derived idiotype vaccination for indolent B cell non-Hodgkin's lymphomas: a focus on FavId. Expert Opin Biol Ther 2005; 5: 841-52.

[62] Reinis M. Drug evaluation: FavId, a patient-specific idiotypic vaccine for non-Hodgkin's lymphoma. Curr Opin Mol Ther 2007; 9: 291-8.

[63] Oudejans JJ, Muris JJ, Cillessen SA, Meijer CJ. T-cell response in B-cell lymphomas: favorable or unfavorable? Clin Cancer Res 2008; 14: 2514 .

[64] Chang KC, Jones D. Reply to the Letter to the Editor from Oudejans et al. Clin Cancer Res 2008; 14: 2515.
[65] Muris JJ, Meijer CJ, Cillessen SA, et al. Prognostic significance of activated cytotoxic T-lymphocytes in primary nodal diffuse large B-cell lymphomas. Leukemia 2004; 18: 589-96.

[66] Hasselblom S, Sigurdadottir M, Hansson U, Nilsson-Ehle H, Ridell B, Andersson PO. The number of tumour-infiltrating TIA-1+ cytotoxic $\mathrm{T}$ cells but not FOXP3+ regulatory $\mathrm{T}$ cells predicts outcome in diffuse large B-cell lymphoma. Br J Haematol 2007;137: $364-$ 73

[67] Muris JJ, Ylstra B, Cillessen SA, et al. Profiling of apoptosis genes allows for clinical stratification of primary nodal diffuse large Bcell lymphomas. Br J Haematol 2007; 136:38-47.

[68] Chang KC, Huang GC, Jones D, Lin YH. Distribution patterns of dendritic cells and $\mathrm{T}$ cells in diffuse large B-cell lymphomas correlate with prognoses. Clin Cancer Res 2007; 13: 6666-72.

[69] Zangani MM, Frøyland M, Qiu GY, et al. Lymphomas can develop from B cells chronically helped by idiotype-specific T cells. J Exp Med 2007; 204: 1181-91.

[70] Donnelly JJ, Ulmer JB, Shiver JW, Liu MA. DNA vaccines. Annu Rev Immunol 1997; 15: 617-48.

[71] Klinman DM. Adjuvant activity of CpG oligodeoxynucleotides. Int Rev Immunol 2006; 25: 135-54.

[72] Hemmi H, Takeuchi O, Kawai T, et al. A Toll-like receptor recognizes bacterial DNA. Nature 2000; 408: 740-5.

[73] Wagner H. The immunobiology of the TLR9 subfamily. Trends Immunol 2004; 25: 381-6.

[74] Lopez-Requena A, Bestagno M, Mateo de Acosta C, et al. Gangliosides, Ab1 and Ab2 antibodies III. The idiotype of antiganglioside mAb P3 is immunogenic in a T cell-dependent manner. Mol Immunol 2007; 44: 2915-22.

[75] Li E, Pedraza A, Bestagno M, Mancardi S, Sanchez R, Burrone O. Mammalian cell expression of dimeric small immune proteins (SIP). Protein Eng 1997; 10: 731-6.

[76] Cesco-Gaspere M, Zentilin L, Giacca M, Burrone OR. Boosting anti-idiotype immune response with recombinant AAV enhances tumour protection induced by gene gun vaccination. Scand J Immunol 2008; 68: 58-66.

[77] Liso A, Benedetti R, Fagioli M, Mariano A, Falini B. Modulatory effects of mycobacterial heat-shock protein 70 in DNA vaccination against lymphoma. Haematologica 2005; 90: 60-5.

[78] Benvenuti F, Burrone OR, Efremov DG. Anti-idiotypic DNA vaccines for lymphoma immunotherapy require the presence of both variable region genes for tumor protection. Gene Ther 2000; 7: 605-11.

[79] Benvenuti F, Burrone OR. Anti-idiotypic antibodies induced by genetic immunisation are directed exclusively against combined $\mathrm{V}(\mathrm{L}) / \mathrm{V}(\mathrm{H})$ determinants. Gene Ther $2001 ; 8$ : 1555-61.

[80] Cesco-Gaspere M, Benvenuti F, Burrone OR. BCL1 lymphoma protection induced by idiotype DNA vaccination is entirely dependent on anti-idiotypic antibodies. Cancer Immunol Immunother 2005; 54: 351-8.

[81] Ullenhag GJ, Spendlove I, Watson NF, et al. A neoadjuvant/adjuvant randomized trial of colorectal cancer patients vaccinated with an anti-idiotypic antibody, 105AD7, mimicking CD55. Clin Cancer Res 2006; 12: 7389-96.

[82] Ullenhag GJ, Spendlove I, Watson NF, Kallmeyer C, PritchardJones K, Durrant LG. T-cell responses in osteosarcoma patients vaccinated with an anti-idiotypic antibody, 105AD7, mimicking CD55. Clin Immunol 2008; 128: 148-54.

[83] Mosolits S, Markovic K, Fagerberg J, et al. T-cell receptor BV gene usage in colorectal carcinoma patients immunised with recombinant Ep-CAM protein or anti-idiotypic antibody. Cancer Immunol Immunother 2005; 54: 557-70.

[84] Posner MC, Niedzwiecki D, Venook AP, et al. A phase II prospective multi-institutional trial of adjuvant active specific immunotherapy following curative resection of colorectal cancer hepatic metastases: cancer and leukemia group B study 89903. Ann Surg Oncol 2008; 15: 158-64.

[85] Tokunaga E, Oki E, Nishida K, et al. Trastuzumab and breast cancer: developments and current status. Int J Clin Oncol 2006; 11 : 199-208.

[86] Pal S, Saha A, Mohanty K, et al. Generation of Her-2/neu vaccine utilizing idiotypic network cascade. Cancer Biol Ther 2007; 6 : 1916-25.

[87] Carter P, Presta L, Gorman CM, et al. Humanization of an antip185HER2 antibody for human cancer therapy. Proc Natl Acad Sci USA 1992; 89: 4285-9. 
[88] Mohanty K, Saha A, Pal S, et al. Anti-tumor immunity induced by an anti-idiotype antibody mimicking human Her-2/neu. Breast Cancer Res Treat 2007; 104: 1-11.

[89] Clarke GN. Etiology of sperm immunity in women. Fertil Steril. 2008 Feb 15 [Epub ahead of print].

[90] Shoenfeld Y, Katz U. IVIg therapy in autoimmunity and related disorders: our experience with a large cohort of patients. Autoimmunity 2005; 38: 123-37.

[91] Bayary J, Dasgupta S, Misra N, et al. Intravenous immunoglobulin in autoimmune disorders: an insight into the immunoregulatory mechanisms. Int Immunopharmacol 2006; 6: 528-34

[92] Oak S, Gilliam LK, Landin-Olsson M, et al. The lack of antiidiotypic antibodies, not the presence of the corresponding autoan- tibodies to glutamate decarboxylase, defines type 1 diabetes. Proc Natl Acad Sci USA 2008; 105: 5471-6.

[93] Hall TR, Bogdani M, Leboeuf RC, et al. Modulation of diabetes in NOD mice by GAD65-specific monoclonal antibodies is epitope specific and accompanied by anti-idiotypic antibodies. Immunology 2008; 123: 547-54.

[94] Lopez-Requena A, Mateo De Acosta C, Vazquez AM, Perez R. Immunogenicity of autologous immunoglobulins: principles and practices. Mol Immunol 2007; 44: 3076-82.

[95] Hernandez T, Lopez-Requena A, De Acosta CM, Mustelier G, Roque-Navarro L, Perez R. B7 and 34B7 monoclonal antibodies: a theoretical approach to the molecular basis of immunoglobulin cross-reactive antibodies. Hybridoma (Larchmt) 2007; 26: 66-72.

(C) López-Requena and Burrone; Licensee Bentham Open.

This is an open access article licensed under the terms of the Creative Commons Attribution Non-Commercial License (http://creativecommons.org/licenses/by$\mathrm{nc} / 3.0 /$ ) which permits unrestricted, non-commercial use, distribution and reproduction in any medium, provided the work is properly cited. 